\title{
Synthesis and Activity of Nitrogenase in Klebsiella pneumoniae Exposed to Low Concentrations of Oxygen
}

\author{
By SUSAN HILL, $\dagger$ G. L. TURNER AND F. J. BERGERSEN* \\ CSIRO, Division of Plant Industry, Canberra, ACT 2601, Australia
}

(Received 14 November 1983)

\begin{abstract}
Effects of very low concentrations of dissolved $\mathrm{O}_{2}$ on nitrogenase activity in Klebsiella pneumoniae were studied in a stirred chamber system which enabled simultaneous measurements of steady-state $\mathrm{O}_{2}$ concentrations, $\mathrm{O}_{2}$ consumption and $\mathrm{C}_{2} \mathrm{H}_{2}$ reduction. A strain carrying a chromosomal nifH : :lac fusion as well as the $\mathrm{Nif}^{+}$plasmid $\mathrm{pRD} 1$, expressed nitrogenase activity with $80 \mathrm{nM}-\mathrm{O}_{2}$, a concentration known to inhibit nif $\mathrm{H}:$ : lac expression by about $50 \%$. Thus nitrogenase activity in vivo was no more sensitive to $\mathrm{O}_{2}$ than expression of nifH::lac. When compared with anaerobic treatments, dissolved $\mathrm{O}_{2}$ near $30 \mathrm{~nm}$ apparently stimulated nitrogenase derepression and enhanced the activity of nitrogenase synthesized anaerobically. Thus, in this organism, $\mathrm{N}_{2}$ fixation occurs in microaerobic as well as anaerobic conditions.
\end{abstract}

\section{INTRODUCTION}

Fixation of $\mathrm{N}_{2}$ in the facultative anaerobe Klebsiella pneumoniae is principally associated with anaerobic metabolic processes, although enhancement by limiting $\mathrm{O}_{2}$ has been obtained in chemostats (Hill, 1976). Excess $\mathrm{O}_{2}$ rapidly inhibits both the activity and synthesis of nitrogenase (St John et al., 1974; Eady et al., 1978). Regulation of synthesis occurs, at least in part, at the level of transcription of nif DNA (Kaluza \& Hennecke, 1981 ; M. Cannon, S. Hill, E. Kavanagh and $\mathrm{F}$. Cannon, unpublished) by a mechanism that probably involves the nif $L$ gene product as a negative controlling element (Hill et al., 1981; Merrick et al., 1982; Buchanan-Wollaston et al., 1981 ; Filser et al., 1983). Such studies have been facilitated by the construction of nif: : lac gene fusions (Dixon et al., 1980), in which the Escherichia coli lac operon is fused into the various nif gene transcriptional units. Expression from the various nif promoters results in the $\mathrm{O}_{2}$-stable enzyme, $\beta$-galactosidase, whose assay can be used to monitor expression of the various nif genes.

Recently Bergersen et al. (1982) employed a technique which exploits leghaemoglobin (Lb) to measure very low $\mathrm{O}_{2}$ concentrations (Bergersen \& Turner, 1979) to determine the influence of $\mathrm{O}_{2}$ on nifH::lac expression (nifHDKY is the operon encoding the nitrogenase complex). At $100 \mathrm{nM}$ $\mathrm{O}_{2}$, a concentration near the apparent $K_{\mathrm{S}}$ of the principal terminal oxidase $\left(80 \mathrm{nM}-\mathrm{O}_{2}\right)$, derepression of nifH::lac was inhibited by $50 \%$ when compared with that in anaerobic treatments. The strain also carried the $\mathrm{Nif}^{+}$plasmid $\mathrm{pRD} 1$, but our earlier experiments did not establish the relative $\mathrm{O}_{2}$ sensitivity of nitrogenase activity and nif $H$ : :lac expression, because $\mathrm{C}_{2} \mathrm{H}_{2}$-reducing activity was not measured in situ. The experimental design has now been modified to show that active nitrogenase is produced at low concentrations of dissolved $\mathrm{O}_{2}$. We also present further evidence that $\mathrm{O}_{2}$ can stimulate derepression of nitrogenase (Bergersen et al., 1982) as well as activity (Hill, 1976).

\section{METHODS}

Media. The media were as described previously (Bergersen et al., 1982) unless otherwise stated. NFDM contained glucose (111 mM) as carbon source. Sucrose D medium was NFDM but with sucrose ( $59 \mathrm{mM})$ as carbon

† Permanent address: ARC Unit of Nitrogen Fixation, The University of Sussex, Brighton BN1 9RQ, UK. $0022-1287 / 84 / 0001-1602 \$ 02.00$ (C) 1984 SGM 
source, and ferric citrate $(0 \cdot 11 \mathrm{mM})$ in place of $\mathrm{FeSO}_{4}$. Resuspension medium was the derepression medium of Bergersen et al. (1982) but with the sucrose concentration raised from 29 to $164 \mathrm{~mm}$. These media contained various concentrations of $\left(\mathrm{NH}_{4}\right)_{2} \mathrm{SO}_{4}$ where indicated. For aerobic derepression in the apparatus described below, derepression medium contained 80-100 $\mu \mathrm{M}$ oxyleghaemoglobin (Lb) prepared as described by Appleby \& Bergersen (1980).

Bacteria and plasmids. UNF767(pRD1) was constructed and tested for plasmid retention as described by Bergersen et al. (1982). There was no indication of plasmid loss during derepression experiments, therefore such tests were not performed after experiments with derepressed populations.

During tests for plasmid retention we observed some bacterial contamination. This was traced to some batches of stock solutions of $\mathrm{Lb}$ which were subsequently sterilized by membrane filtration. We consider that the level of $\mathrm{N}_{2}$-fixing contamination was insufficient to have influenced the results.

Cultures. For derepression experiments, batch cultures under $\mathrm{N}_{2}$ were grown in either NFDM or sucrose D, both with $\left(\mathrm{NH}_{4}\right)_{2} \mathrm{SO}_{4}(10 \mathrm{mM})$, harvested by centrifugation under $\mathrm{Ar}$, and resuspended in $2 \mathrm{ml}$ ice-cooled derepression medium under Ar as described previously (Bergersen et al., 1982). At zero-time, portions $(0 \cdot 2-0 \cdot 6 \mathrm{ml})$ were then transferred by syringe to the reaction chambers described below. For experiments with derepressed populations, batch cultures were grown in sucrose $\mathrm{D}$ and contained, for overnight anaerobic growth under $\mathrm{N}_{2}$, a small initial amount $(1.5 \mathrm{~mm})$ of $\left(\mathrm{NH}_{4}\right)_{2} \mathrm{SO}_{4}$. Four $40 \mathrm{ml}$ portions from two $100 \mathrm{ml}$ cultures were harvested by centrifugation under $\mathrm{N}_{2}$, and resuspended in $2 \mathrm{ml}$ ice-cooled resuspension medium under $\mathrm{N}_{2}$. Portions $(0 \cdot 1-$ $0.5 \mathrm{ml}$ ) were then transferred by syringe to the reaction chambers described below.

Derepression experiments. Synthesis of nitrogenase was monitored by assay of $\beta$-galactosidase produced from the nifH: :lacDKY operon and by assay of activity of nitrogenase produced from the nif of pRD1. Anaerobic and $\mathrm{O}_{2}$ treatments were run in parallel at $30^{\circ} \mathrm{C}$, by procedures similar to those in Bergersen et al. (1982). The following modifications allowed nitrogenase $\left(\mathrm{C}_{2} \mathrm{H}_{2}\right.$-reducing $)$ activity to be measured in situ.

For anaerobic treatments the gas composition in the capped $100 \mathrm{ml}$ flasks, containing $16 \mathrm{ml}$ of derepression media at $30{ }^{\circ} \mathrm{C}$, was $20 \%(\mathrm{v} / \mathrm{v}) \mathrm{C}_{2} \mathrm{H}_{2}$ in Ar. In addition to withdrawing culture samples $(1 \cdot 1 \mathrm{ml})$ for $\beta$-galactosidase assays, samples $(0.2$ or $0.5 \mathrm{ml})$ of gas were removed in Ar-flushed syringes for gas analysis.

For $\mathrm{O}_{2}$ treatments in flasks, the procedure was as above but the gas composition was $20 \% \mathrm{C}_{2} \mathrm{H}_{2}$ and either $0.5 \%$ or $1.0 \%(\mathrm{v} / \mathrm{v}) \mathrm{O}_{2}$ in Ar. For $\mathrm{O}_{2}$ treatments, with Lb, the stirred flow chamber apparatus of Bergersen \& Turner (1979), described and illustrated previously (Bergersen et al., 1982), was modified as follows.

(1) A cylindrical gas reservoir (3 1) fitted with a threaded piston (Turner \& Gibson, 1980) was evacuated and then filled with $20 \% \mathrm{O}_{2}$, or $40 \% \mathrm{O}_{2}$, and $20 \% \mathrm{C}_{2} \mathrm{H}_{2}$ in Ar. The greater $\mathrm{O}_{2}$ level was used in one experiment where a high $\mathrm{O}_{2}$ concentration was maintained. The gas reservoir was then connected to the evacuated head-space of the medium reservoir which contained the degassed derepression medium plus $\mathbf{L} b$. The head-space was then brought to, and maintained at, atmospheric pressure with the aid of a manometer, by adjusting the piston of the cylinder.

(2) In addition to withdrawing culture samples $(1 \cdot 1 \mathrm{ml})$ from the reaction chamber for $\beta$-galactosidase assays, samples $(4 \mathrm{ml})$ of the effluent flowing from the spectrophotometer flow cell were collected in a syringe for subsequent analysis of dissolved gases (Bergersen \& Turner, 1979; Turner \& Gibson, 1980). The concentration of free $\mathrm{O}_{2}$ and the rate of $\mathrm{O}_{2}$ consumption in the reaction chamber were calculated as described by Bergersen \& Turner (1979) and Bergersen et al. (1982).

Previously the aggregation of strain UNF767(pRD1) in the stirred reaction chamber of $\mathrm{O}_{2}$-treatments had been prevented by using the derepression medium in place of NFDM. However, although the same derepression medium was used in the present work, some loss of bacteria caused by aggregation and occlusion in the filter membrane occurred during the later stages of derepression. It was most pronounced when high $\mathrm{O}_{2}$ concentrations with high flow rates were maintained but was not due to the presence of leghaemoglobin. The reason for this aggregation is unknown.

Experiments with derepressed populations. Anaerobic and $\mathrm{O}_{2}$ treatments were run in parallel at $30^{\circ} \mathrm{C}$. The procedures were similar to those for derepression experiments except that resuspension medium was used in place of derepression medium, $\mathrm{N}_{2}$ was used in place of $\mathrm{Ar}$ as diluent gas, and each treatment lasted for only $2 \mathrm{~h}$. Thus several different $\mathrm{O}_{2}$ concentrations could be tested on a particular population. Between each $\mathrm{O}_{2}$ treatment the reaction chamber was washed out, refilled with medium and reconnected to the medium reservoir. A sample $(0 \cdot 1$ $0.5 \mathrm{ml}$ ) of ice-cooled bacterial suspension was injected into the reaction chamber and, at the same time, into a flask for the anaerobic treatment. Samples of effluent and of gas, from both $\mathrm{O}_{2}$ and anaerobic treatments, were removed as described for derepression experiments.

Treatment of samples of assays. Samples of organisms were collected during derepression experiments and assayed for the amount of $\beta$-galactosidase present after chloroform-treatment (Bergersen et al., 1982).

Nitrogenase activity was assayed by the production of $\mathrm{C}_{2} \mathrm{H}_{4}$ from $\mathrm{C}_{2} \mathrm{H}_{2}$ measured by gas chromatography (Turner \& Gibson, 1980). For anaerobic treatments the activity was calculated from the rate of accumulation of $\mathrm{C}_{2} \mathrm{H}_{4}$ in the gas phase above the culture. For $\mathrm{O}_{2}$ treatments in the stirred chamber, dissolved gases were recovered from samples of effluent by decompression (Turner \& Gibson, 1980). The rate of $\mathrm{C}_{2} \mathrm{H}_{4}$ production, in derepression experiments, was calculated from the concentration of $\mathrm{C}_{2} \mathrm{H}_{4}$ in the sample and the flux of derepression medium 
through the reaction chamber; for experiments with derepressed populations the steady-state level of $\mathrm{C}_{2} \mathrm{H}_{4}$ production was determined (Bergersen \& Turner, 1979).

Hydrogen was measured by gas chromatography (Turner \& Gibson, 1980). Dry weights were estimated as described by Bergersen et al. (1982), and nitrogenase activity, $\mathrm{O}_{2}$ consumption and $\mathrm{H}_{2}$ evolution were expressed in terms of dry weight.

\section{RESULTS}

Stimulation of derepression by $\mathrm{O}_{2}$ in shaken flasks

During preliminary derepression experiments in flasks in the absence of $\mathrm{Lb}$, levels of $\beta$ galactosidase were slightly higher under an initial $\mathrm{pO}_{2}$ of either 0.5 or $1.0 \mathrm{kPa}$ when compared with anaerobic treatments (Fig. 1 a). Concomitant derepression of $\mathrm{C}_{2} \mathrm{H}_{2}$ reduction in flasks was not influenced by $\mathrm{O}_{2}$ (Fig. 1 b). For these and our earlier experiments (Bergersen et al., 1982) sucrose was used as the carbon source for anaerobic growth with $\mathrm{NH}_{4}^{+}$and for derepression. Similar results were obtained in flasks when glucose replaced the sucrose (data not shown). In contrast, expression of nifH: :lac and appearance of $\mathrm{C}_{2} \mathrm{H}_{2}$ reduction occurred significantly
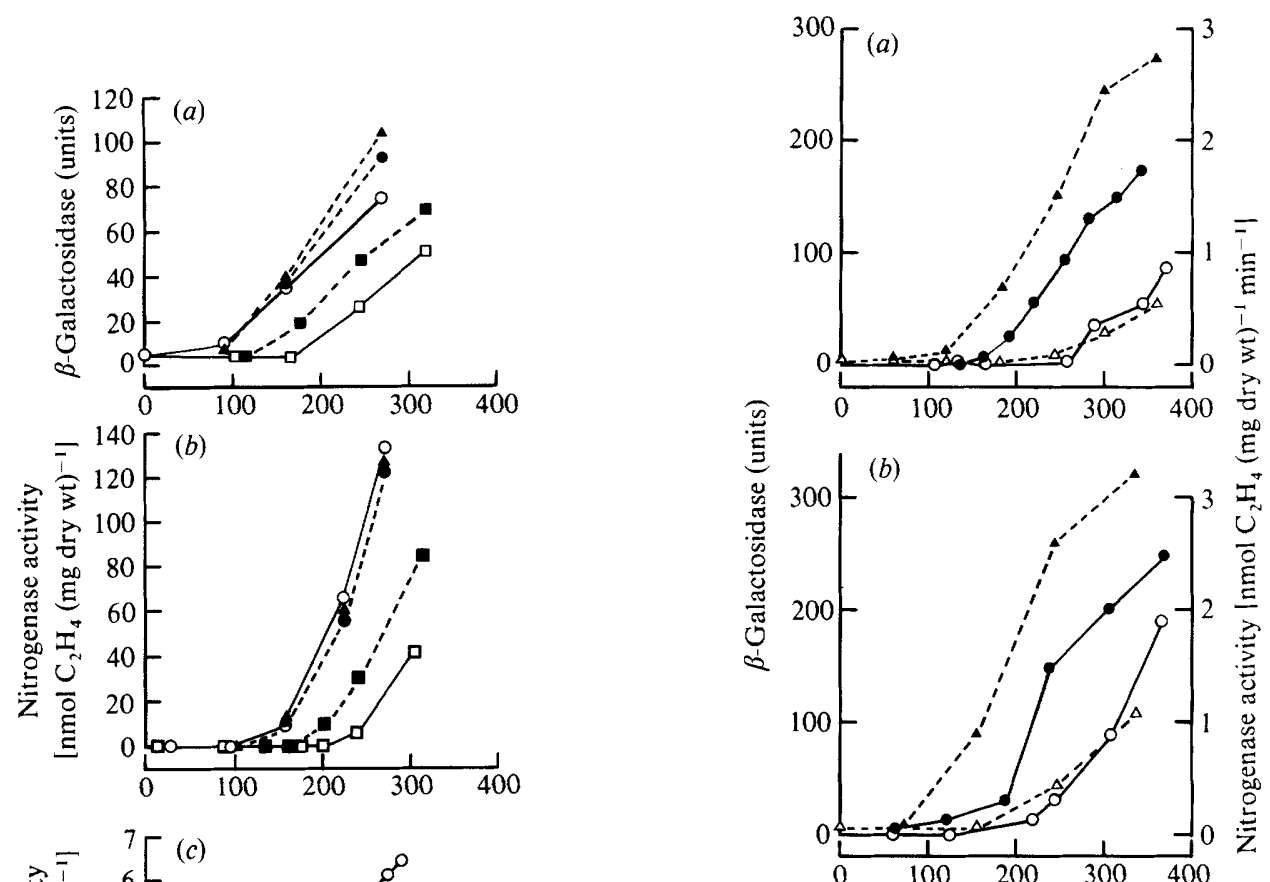

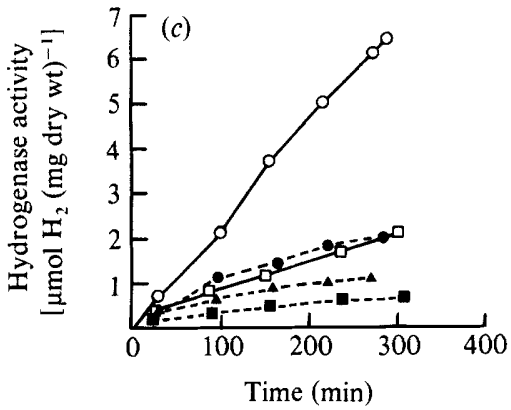

Fig. 1

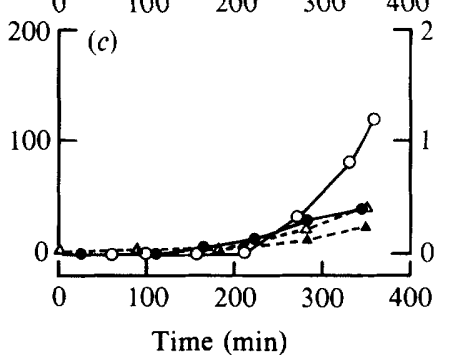

Fig. 2

Fig. 1. Influence of $\mathrm{O}_{2}$ on sucrose-supported derepression of nifH::lac (a) and nitrogenase (b) with concomitant $\mathrm{H}_{2}$ evolution $(c)$. Derepression was in flasks under anaerobiosis $(\mathrm{O}, \square)$ or with $\mathrm{O}_{2}$ provided initially at either $0.5 \mathrm{kPa}(\boldsymbol{O}, \mathbf{\square})$ or $1.0 \mathrm{kPa}(\boldsymbol{\Delta})$, and preceding anaerobic growth with $\mathrm{NH}_{4}^{+}$ was supported by either sucrose (circles and triangles) or glucose (squares).

Fig. 2. Derepression of nifH : : lac $(\Delta, \Delta)$ and nitrogenase $(O, \bigcirc)$ with either $(a) 17 \mathrm{nM}-\mathrm{O}_{2},(b) 36 \mathrm{nM}$ $\mathrm{O}_{2}$ or $(c) 88 \mathrm{nM}-\mathrm{O}_{2}$ (filled symbols) compared with anaerobic treatments (open symbols). 


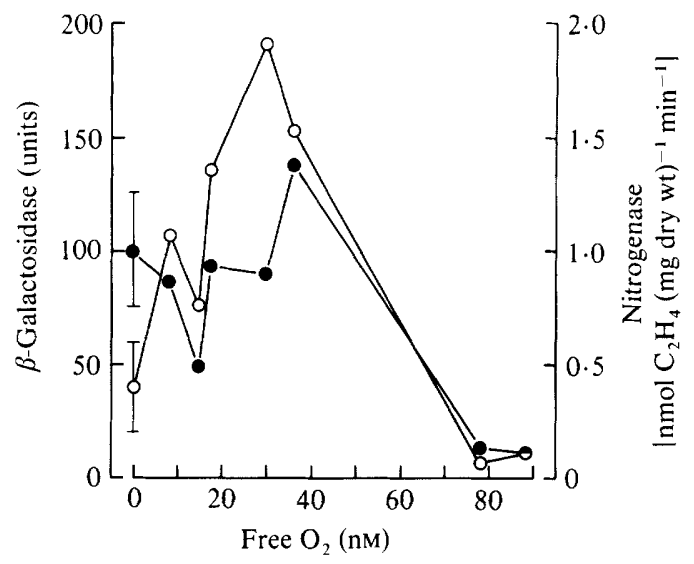

Fig. 3. Influence of $\mathrm{O}_{2}$ concentration on the rate of increase of $\beta$-galactosidase $(O)$ and of nitrogenase (O) activities during derepression. The activities measured shortly after their appearance and then after a further $2 \mathrm{~h}$ were used to estimate the rate of increase. The vertical bars indicate the standard deviations for anaerobic values.

earlier with $\mathrm{O}_{2}$ present when the removal of $\mathrm{NH}_{4}^{+}$was accompanied by a change in carbon source from glucose for growth to sucrose for derepression (Fig. 1 $a, b$ ). Anaerobic expression of nifH : :lac and $\mathrm{C}_{2} \mathrm{H}_{2}$ reduction, during derepression supported by sucrose, was delayed when the carbon source for growth was glucose in place of sucrose (Fig. $1 a, b$ ).

Klebsiella pneumoniae possesses a hydrogenase, which dissipates reducing power generated during fermentation. Although it is inhibited by $\mathrm{C}_{2} \mathrm{H}_{2}$ (Smith et al., 1976), significant rates of $\mathrm{H}_{2}$ evolution were detected under the derepressing conditions in flasks with $20 \% \mathrm{C}_{2} \mathrm{H}_{2}$ (Fig. 1c) where $\mathrm{H}_{2}$ evolution from nitrogenase would be negligible. The anaerobic rates of $\mathrm{H}_{2}$ evolution were similar when growth and derepression were supported by either glucose (data not shown) or sucrose (Fig. 1c). However, when the shift to the derepressing condition was accompanied by the change in carbon source, the rate was significantly lower (Fig. 1c), suggesting that fermentation was restrained.

\section{Effects of controlled levels of $\mathrm{O}_{2}$ on synthesis and activity of nitrogenase}

Synthesis and activity of nitrogenase and respiration were measured simultaneously during derepression in $\mathrm{O}_{2}$ treatments with $\mathrm{Lb}$ in the stirred chamber system. Synthesis (units of $\beta$ galactosidase $)$ and activity $\left(\mathrm{C}_{2} \mathrm{H}_{2}\right.$-reduction) were detected earlier when $\mathrm{O}_{2}$ was maintained at concentrations ranging from 8 to $36 \mathrm{nM}$ than in anaerobic treatments (Fig. 2). The rate of derepression was also enhanced by these levels of $\mathrm{O}_{2}$ and $2 \mathrm{~h}$ after the onset of expression levels of $\beta$-galactosidase with $30 \mathrm{nM}-\mathrm{O}_{2}$ were approximately four times greater than those in anaerobic treatments (Fig. 3). The rate of increase of nitrogenase activity was also stimulated by low concentrations of $\mathrm{O}_{2}$ but not to the same extent (Fig. 3). At low $\mathrm{O}_{2}$ concentrations, as expected, detection of $\beta$-galactosidase preceded detection of nitrogenase (Fig. $2 a, b$ ). At higher $\mathrm{O}_{2}$ concentration (near $80 \mathrm{nM}$ ), as found by Bergersen et al. (1982), derepression was partially inhibited, but the time separating the appearance of the two activities was shorter (Fig. $2 c$ ). However with the latter $\mathrm{O}_{2}$ concentrations, the bacteria tended to aggregate, so $\mathrm{C}_{2} \mathrm{H}_{4}$ production may represent nitrogenase activities under somewhat lower dissolved $\mathrm{O}_{2}$ concentrations than that indicated by the spectrum of $\mathrm{Lb}$.

The ability of cultures to reduce $\mathrm{C}_{2} \mathrm{H}_{2}$ during derepression with $\mathrm{O}_{2}$ present may be a consequence of protective adaptation to the ambient aerobic conditions. Therefore populations derepressed under anaerobic conditions were tested for ability to reduce $\mathrm{C}_{2} \mathrm{H}_{2}$ at low $\mathrm{O}_{2}$ concentrations with sucrose as carbon source. Three different derepressed populations of anaerobic activity $16 \pm 9 \mathrm{nmol} \mathrm{C}_{2} \mathrm{H}_{4} \mathrm{~min}^{-1}\left(\mathrm{mg}\right.$ dry wt) ${ }^{-1}$ (which was unaffected by storage on ice) were used. For each steady-state $\mathrm{O}_{2}$ concentration (maintained for 1-2 h), a fresh sample of 


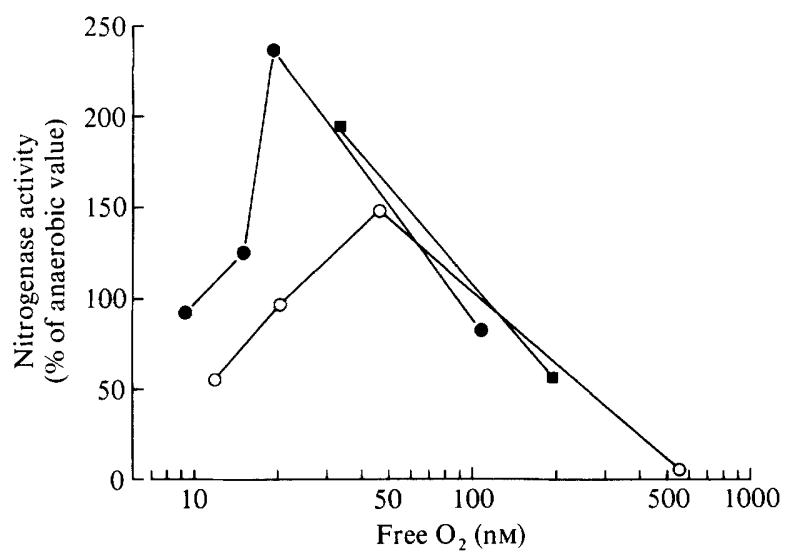

Fig. 4. Influence of dissolved $\mathrm{O}_{2}$ concentration on nitrogenase activity in populations derepressed under anaerobic conditions. Nitrogenase activity ( $\mathrm{nmol} \mathrm{C}_{2} \mathrm{H}_{4} \mathrm{mg}^{-1} \mathrm{~min}^{-1}$ ) is expressed as a percentage of that in anaerobic treatments. The different symbols represent three different experiments.

the ice-cooled suspension was used, and in parallel the activity was measured anaerobically. Nitrogenase activity was highest (twice the anaerobic rate), at about $30 \mathrm{nM}-\mathrm{O}_{2}$ (Fig. 4). At concentrations above $80 \mathrm{nM}-\mathrm{O}_{2}$, which is the apparent $K_{\mathrm{s}}$ of the principal terminal oxidase (Bergersen et al., 1982), activity was partially inhibited, but was still detected with $550 \mathrm{nM}-\mathrm{O}_{2}$ $\left(2.6 \mathrm{nmol} \mathrm{C}_{2} \mathrm{H}_{4} \mathrm{~min}^{-1}(\mathrm{mg} \text { dry } \mathrm{wt})^{-1}\right.$. The reason for the apparent decrease in activity compared with the anaerobic level (Fig. 4), when the $\mathrm{O}_{2}$ concentration was maintained below $20 \mathrm{nM}$, is unclear. With anaerobically derepressed bacteria there was no aggregation in the stirred chamber. Over all experiments rates of $\mathrm{C}_{2} \mathrm{H}_{2}$ reduction were proportional to $\mathrm{O}_{2}$ consumption up to $80 \mathrm{nmol} \mathrm{O}_{2} \min ^{-1}$ (mg dry wt) ${ }^{-1}, 2.5 \mathrm{nmol} \mathrm{O}_{2}$ being consumed per mol $\mathrm{C}_{2} \mathrm{H}_{2}$ reduced above the anaerobic rate (cf. Bergersen, 1978).

\section{DISCUSSION}

In our earlier work (Bergersen et al., 1982) samples were removed at timed intervals from the stirred chamber containing the derepressing culture of UNF767(pRD1), maintained at a low $\mathrm{O}_{2}$ concentration with $\mathrm{Lb}$, and nitrogenase activity in the samples was measured anaerobically. This assay may have misrepresented the activity in the chamber because inhibition of nitrogenase by $\mathrm{O}_{2}$ is partially reversible (Hill, 1976) and relief from $\mathrm{O}_{2}$ repression of nifHDK mRNA and polypeptide synthesis is very rapid (M. Cannon, S. Hill, E. Kavanagh and F. Cannon, unpublished). The processes regulating nifH: :lac expression may be more tolerant of $\mathrm{O}_{2}$ than one or more subsequent steps needed for nitrogenase activity. The present experiments were therefore designed to measure nitrogenase activity during derepression in the presence of $\mathrm{O}_{2}$ and to establish whether nifH:: lac expression could be enhanced by low concentrations of $\mathrm{O}_{2}$. Nitrogenase activity was no more sensitive to $\mathrm{O}_{2}$ than expression of nifH::lac. This also implies that none of the synthetic processes, following transcription from the nif $H$ promoter (measured as expression of nifH::lac) and resulting in the appearance of $\mathrm{C}_{2} \mathrm{H}_{2}$ reduction, are markedly inhibited by microaerobic conditions. Besides the translation of the nif mRNA, such processes involve the subsequent assembly and processing of the polypeptides to yield the two $\mathrm{O}_{2}$-sensitive metal-containing nitrogenase components, and the provision of sources of reducing power and ATP for activity.

Jensen \& Kennedy (1982) showed that anaerobic nitrogenase synthesis is selectively curtailed when the ATP level in vivo is low. Thus the slower derepression after the change in carbon source may reflect the time taken for relief from catabolic repression for sucrose utilization. The provision of some $\mathrm{O}_{2}$ during derepression following the change in carbon source, may 
temporarily upgrade the energy status and thereby allow earlier and more rapid derepression of nitrogenase. Such an upgrading might be brought about by a stimulation of invertase induction thus lifting the restraint on fermentation. Conditions of low $\mathrm{O}_{2}$ supply giving rise to early nitrogenase derepression in flasks, rather than stimulating, partially inhibited $\mathrm{H}_{2}$ evolution (Fig. 1c); however, the presence of $\mathrm{O}_{2}$ may suppress fermentative processes and aerobic catabolic processes supported by endogenous substrates might be responsible for the upgrading.

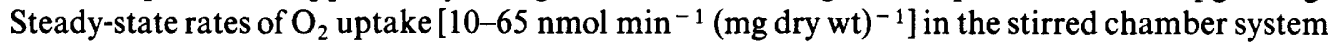
maintained at $\mathrm{O}_{2}$ concentrations ranging from 8 to $36 \mathrm{nM}$, were similar to those observed by Bergersen et al. (1982), suggesting that respiratory activity was not affected by the change in carbon source. An enhancement of catabolic activity by $\mathrm{O}_{2}$ could lead to a general effect on macromolecular synthesis rather than to a more specific effect on energy status regulating nif gene expression. Further work should reveal whether the apparent stimulation by $\mathrm{O}_{2}$ of nitrogenase derepression can be correlated with elevated levels of ATP.

The activity of nitrogenase, fully derepressed during anaerobic growth, was also clearly enhanced with free, dissolved $\mathrm{O}_{2}$ at $30 \mathrm{nM}$. This, together with the correlation between enhancement of nitrogenase activity and $\mathrm{O}_{2}$ consumption, indicates involvement of increased energetic efficiency of aerobic versus anaerobic pathways of metabolism supporting nitrogenase. The observations are consistent with evidence that nitrogenase activity in $K$. pneumoniae can be supported, in part, by aerobic processes (Hill, 1976). This hypothesis has been challenged by Kashket (1981), who was unable to detect an electrical component $(\Delta \psi)$ of the protonmotive force in anaerobic $\mathrm{N}_{2}$-fixing batch cultures of $K$. pneumoniae strain M5al. However, $\mathrm{O}_{2}$ was apparently excluded during the measurements, so her results do not preclude the possibility that, as a result of aerobic respiratory activity, a sufficient protonmotive force is generated across the membrane to yield additional supplies of either reducing power or ATP for nitrogenase activity.

We thank Dr C. Kennedy and Prof. J. R. Postgate for critical revisions to the manuscript, and the ARC and CSIRO for financial support for S.H. to visit the Division of Plant Industry.

\section{REFERENCES}

Appleby, C. A. \& Bergersen, F. J. (1980). Preparation and experimental use of leghaemoglobin. In Methods for Evaluating Biological Nitrogen Fixation, pp. 314-335. Edited by F. J. Bergersen. Chichester: Wiley.

BERGERSEN, F. J. (1978). Leghaemoglobin, oxygen supply and nitrogen fixation studies with soybean nodules. In Limitations and Potentials for Biological Nitrogen Fixation in the Tropics, pp. 247-261. Edited by J. Dobereiner, R. H. Burris, A. Hollaender, A. Franco, C. Neyra \& D. B. Scott. New York: Plenum.

Bergersen, F. J. \& Turner, G. L. (1979). Systems utilising oxygenated leghaemoglobin and myoglobin as sources of free dissolved $\mathrm{O}_{2}$ at low concentrations for experiments with bacteria. Analytical Biochemistry 96, 165-174.

Bergersen, F. J., Kennedy, C. \& Hill, S. (1982). Influence of low oxygen concentration on derepression of nitrogenase in Klebsiella pneumoniae. Journal of General Microbiology 128, 909-915.

Buchanan-Wollaston, V., Cannon, M. C., Beynon, J. L. \& CANNON, F. C. (1981). Role of the nif $A$ gene product in the regulation of nif expression in Klebsiella pneumoniae. Nature, London 194, 776-778.

DIXON, R., EADY, R. R., EsPIN, G., HILl, S., IACCARINo, M., KAHN, D. \& MERRICK, M. (1980). Analysis of regulation of Klebsiella pneumoniae nitrogen fixation (nif) gene cluster with gene fusions. Nature, London 286, 128-132.
EAdy, R. R., Issack, R., Kennedy, C., Postgate, J. R. \& RATCLIFFE, H. D. (1978). Nitrogenase in Klebsiella pneumoniae: comparison of ammonia and oxygen regulation. Journal of General Microbiology 104, 277285.

Filser, M., Merrick, M. \& Cannon, F. C. (1983). Cloning and characterisation of nif $L A$ regulatory mutations from Klebsiella pneumoniae. Molecular and General Genetics 191, 485-491.

HILL, S. (1976). Influence of atmospheric oxygen concentration on acetylene reduction and efficiency of nitrogen fixation in intact Klebsiella pneumoniae. Journal of General Microbiology 93, 335-345.

Hill, S., Kennedy, C., Kavanagh, E., Goldberg, R. B. \& HaNAU, R. (1981). Nitrogen fixation gene (nif $L$ ) involved in oxygen regulation of nitrogenase synthesis in Klebsiella pneumoniae. Nature, London 290, 424-426.

Jensen, J. S. \& Kennedy, C. (1982). Pleiotropic effect of his gene mutations on nitrogen fixation in Klebsiella pneumoniae. EMBO Journal 1, 197-204.

KaluZA, K. \& HenNecke, H. (1981). Regulation of nitrogenase messenger RNA synthesis and stability in Klebsiella pneumoniae. Archives of Microbiology 130, 38-43.

KASHKET, E. R. (1981). Effects of aerobiosis and nitrogen source on the proton motive force in growing Escherichia coli and Klebsiella pneumoniae cells. Journal of Bacteriology 146, 377-384. 
Merrick, M., Hill, S., Hennecke, H., Hahn, M. DiXon, R. \& KENNEDY, C. (1982). Repressor properties of the nifL gene product in Klebsiella pneumoniae. Molecular and General Genetics 185, 7581.

Smith, L. A., Hill, S. \& Yates, M. G. (1976). Inhibition by acetylene of conventional hydrogenase in nitrogen-fixing bacteria. Nature, London 262, 209210 .
St John, R. T., Shah, V. K. \& Brill, W. J. (1974). Regulation of nitrogenase synthesis by oxygen in Klebsiella pneumoniae. Journal of Bacteriology 119 , 266-269.

TuRner, G. L. \& Gibson, A. H. (1980). Measurement of nitrogen fixation by indirect means. In Methods for Evaluating Biological Nitrogen Fixation, pp. 111138. Edited by F. J. Bergersen. Chichester: Wiley. 